\title{
Role of Total Quality Management in Kenyan Coffee House Revenue Generation
}

\author{
John Ndung'u Kirugumi \\ Student: Dedan Kimathi University of Technology \\ Dr. Lilian Mwenda \\ Lecturer: Dedan Kimathi University of Technology \\ Dr. Anita Wachira \\ Lecturer: Dedan Kimathi University of Technology
}

\begin{abstract}
The study's aim was to analyze the role of total quality management in Kenyan coffee house revenue generation. Specifically the study sought to; assess the effects of continuous process improvement on coffee house revenue generation, analyze the impact of supplier partnering on coffee house revenue generation, evaluate the effects of customer satisfaction on coffee house revenue generation, and explore the effect of quality control on coffee house revenue generation. Descriptive research design was used. A regression model was generated to establish the relationship between the dependent variable, (revenue generation) and the independent variables, (continuous process improvement, supplier partnering, customer satisfaction and quality control). The results indicated that customer satisfaction had the greatest effect on revenue generation followed by continuous process improvement, while supplier partnering had the least effect. The study recommends that themed coffee houses need to focus on satisfying customers in order to increase their revenue generation.
\end{abstract}

Key Words: Total Quality Management, Continuous Process Improvement, Quality Control Supplier Partnering and Customer Satisfaction, Themed Coffee Houses

\section{INTRODUCTION}

A coffeehouse serves as an informal club for its regular members. The global coffee market is currently plagued by two paradoxes; a coffee boom in consuming countries, and a coffee crisis in producing countries, over supply of low quality coffee and shortage of high quality coffee, which are actually driving the coffee market (Daviron and Ponte, 2005). After the termination of the International Coffee Agreement between producing and consuming countries in 1989, the coffee market has been in a flux, with market forces and over supply bringing down the coffee prices and hence income of farmers. According to International Coffee Organization (ICO, 2004), earnings by coffee producing countries were some 10-12 billion dollars fifteen years ago which has changed to around five billion dollars in 2003. Although the percentage share of the retail coffee price that goes to the farmer has gone above $10 \%$ in recent times, it has not offset the declining prices (Sayer, 2001). By 2009, Brazil was the world leader in production of green coffee with $34 \%$ of the world coffee, followed by Vietnam, Indonesia and Colombia. In Africa, Ethiopia is inarguably the largest exporter of coffee having a world share of $6 \%$ in the global output (Belder and Besterfield, 2006). Other coffee producing countries in Africa include Angola, Burundi, Cameroon, Congo, Ivory Coast, Kenya, Madagascar, Rwanda, 
Tanzania, Uganda and Zambia (ICO, 2004). In East Africa the coffee producers are Ethiopia, Uganda, Kenya and Tanzania. Kenya produces almost exclusively washed Arabica Coffee of the Bourbon type although there is a very small production of Robusta Coffee that is grown in the low altitude areas (Howden, 2012). Kenyan coffee is characterized by very sharp acidity, full body and very pointed fine flavor. This makes it acceptable to many coffee drinkers although there are those that will complain about the high sharpness of the acidity. In terms of production, cooperatives come up with 55\% of the crop while the large estates come up with the rest (45\%). Cooperatives have better quality coffee that is exclusively grown along the mountains. The paradox of the Kenya coffee industry is that while the country has consistently produced the best quality beans in the world, only $2 \%$ of the product is consumed locally (Varqa, 2008).

\section{STATEMENT OF THE PROBLEM}

A cup of coffee in themed Kenyan coffeehouses is retailing at Kshs 200 on average compared to tea which retails at Kshs100, hence the low consumption of coffee. High local consumption of coffee will give farmers bargaining power in auctions, give the Kenyan government an upper hand in setting the best prices for the coffee and earn foreign currency which will strengthen Kenya's balance of payments while achieving both the economic and social pillars of her Vision 2030. The government, through the Coffee Development Fund, is seeking to increase consumption of coffee locally by giving incentives for establishment of coffeehouses. The study seeks to enjoin this government initiative through deployment of Total Quality Management in the generation of sales revenues in the coffee houses.

\section{Research Objective}

The research objectives were;

1. To assess the effects of continuous process improvement on coffee house revenue generation.

2. To analyze the impact of suppliers partnering on coffee house revenue generation.

3. To evaluate the effects of customer satisfaction on coffee house revenue generation.

4. To explore the effect of quality control on coffee house revenue generation.

\section{Continuous Process Improvement}

\section{LITERATURE REVIEW}

Studies have shown that traditionally the quality costs were seen from a production oriented point of view, taking only costs of deviating from specification into account and since then the understanding of the subject area has developed (Sörqvist and Vrat, 2005). The area has since become wider as the term quality has developed a wider meaning. Still there is no agreement on a single general definition of quality costs, but it is usually considered to be composed of the sum of conformance plus non-conformance costs (Schiffauerova and Thomson, 2006). Juran defined quality costs as "the costs that would disappear if a company's products and its processes were to be perfect (Sörqvist and Vrat, 2005). The rather wide definition of quality costs indicate that the concept comprises a correspondingly wide range of costs, many of which are hidden. At times the quality costs are described as an iceberg (Campanella, 2001). Campanella proposed to categorize quality costs into prevention, appraisal, internal failure and external failure costs. Quality costs are also sometimes divided into what is referred to as conformance and non-conformance costs. Conformance costs are associated with making sure products or services conform to specified standards and consist of prevention and appraisal costs. Non-conformance costs arise from products or services that do not comply with quality standards and consist of the internal and external failure costs. Most importantly, however, is not the categorization of quality costs but that the quality costing system is tailored to suit the needs of the organization (Pursglove and Dale, 2005). 


\section{Supplier Partnering}

Empirical studies show that supplier partnering can be an extended relationship between buyers and sellers based on confidence, credibility, and mutual benefit. The buyer, on its part, provides long-term contracts and assurance of only a small number of competing suppliers. In reciprocation, the seller implements customers' suggestions and commits to continuous improvement in quality of products and delivery time. In today's business, many buying firms pursue aggressive strategies such as supplier partnering and outsourcing in order to increase their future rate of capabilities improvement (Trent and Callahan, 1993). There are several reasons behind pursuing aggressive strategies. Firstly, manufacturers are focusing on their core competencies and areas of technical expertise. Secondly, developing an effective supply base management strategy can help counter the competitive pressures brought about by intense worldwide competition. Thirdly, suppliers can directly support a firm's ability to innovate in the critical areas of product and process technology. A study showed $95 \%$ of the business units sampled indicated supplier contributions were increasing in terms of importance. Supplier partnering has been ubiquitous in Japan and Korea for a number of years, but is less evident in United States firms due to a perceived lack of instant return on investment. Interestingly, this practice was recognized early in the 1900's by the American automotive industry when Ford required improved supplier capacity (Krause, Handfield, and Tyler, 2006).

\section{Customer Satisfaction}

Previous research has explored the link between customer focus, satisfaction and business performance broadly. The general consensus is that higher customer satisfaction leads to higher levels of repurchase intent, customer advocacy, and customer retention (Anderson and Sullivan, 1993). While these studies have generally found a significant relationship between, satisfactions and repurchase intention, a good deal of variation in this relationship remains unexplained. However, other researchers have questioned the use of repurchase intentions as a surrogate of actual customer behavior. They have noted that many customers with high satisfaction and/or repurchase intentions ultimately defect, and, conversely, some customers with low satisfaction and repurchase intent often stay with a supplier. Both of these outcomes are contrary to the main effect of satisfaction-repurchase intentions, suggesting complexity and researchers should explore on customer focus and satisfaction.

\section{Quality Control}

Dale and Schindler (2003) argue that Ishikawa has been credited with originating the concept of quality circles and cause-and-effect diagrams. Ishikawa claimed that there had been a period of over-emphasis on statistical quality control (in Japan), and as a result, people disliked quality control. They saw it as something unpleasant because they were given complex tools rather than simple ones. Additionally, the resulting standardization of products and processes and the creation of rigid specification of standards became a burden that not only made change difficult, but also made people feel bound by regulations. Ishikawa took the concepts proposed by people like Deming and Juran and brought them to the level of the common worker (Rao, Odendaal and Roodt, 1996). There appears to be no uniform understanding and definition of the meaning of the term quality and even well-known authors seem to have different perspectives on this issue.

According to Reeves and Bednar (1994), a search for the definition of quality has yielded inconsistent results. The two researchers emphasize that regardless of the time period or context in which quality is examined, the concept has had multiple and often muddled definitions and has been used to describe a wide variety of phenomena. The strategies and 
tools for assuring quality may have changed, but the basic customer expectations have been fairly constant for a long time (Hoyer, 2009).

\section{Operational Framework}

The operational framework shows the measuring parameters of both the independent variables and the dependent variables.

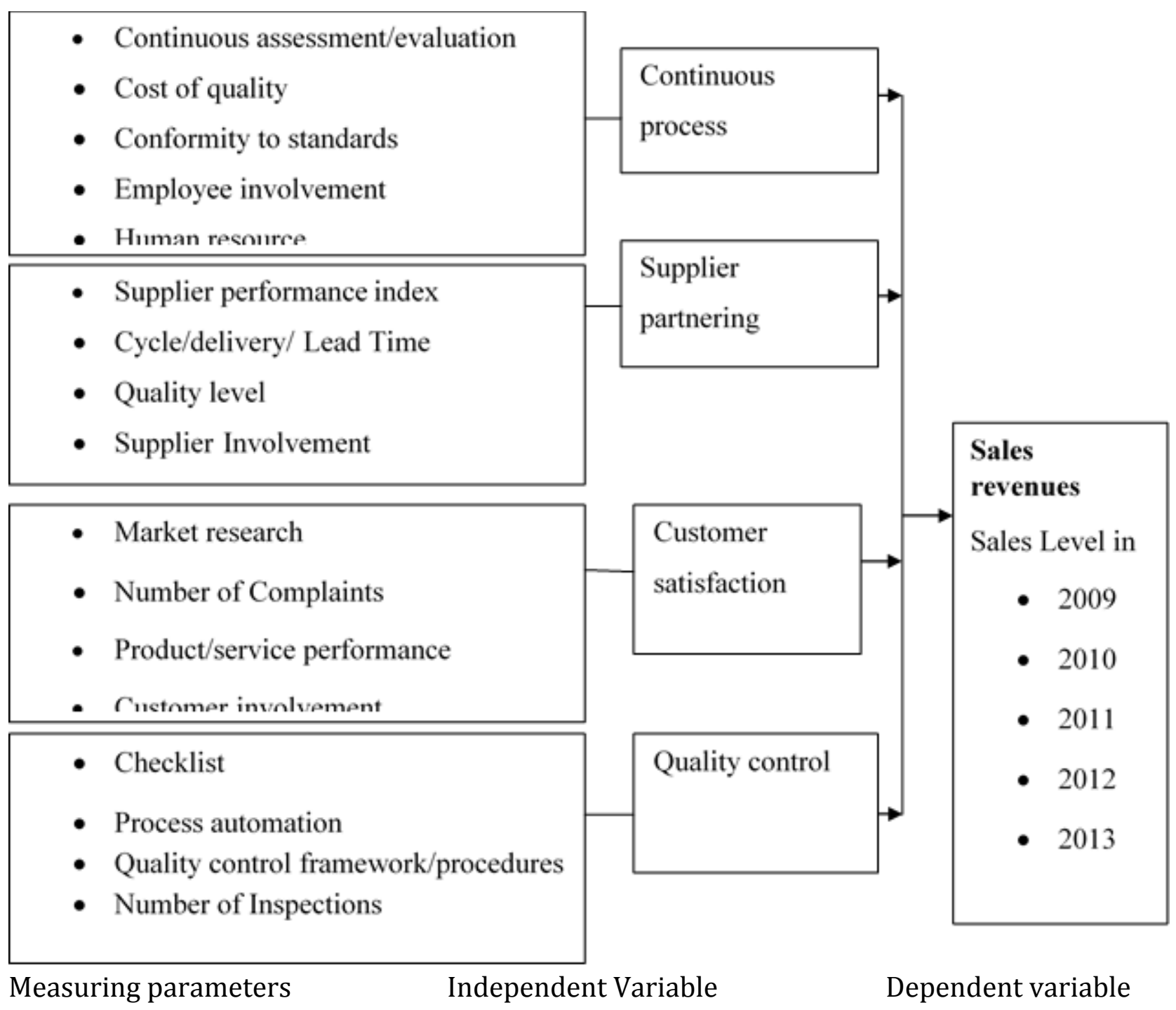

Figure 2.5: Operational framework of the study

\section{METHODOLOGY}

In this study, descriptive research design was adopted. The population of interest were branch managers in the 41 themed coffee houses in Nairobi, Mombasa and Nakuru. The branch managers had been chosen due to their vulnerability to quality control lapses and their role in policy formulation and implementation in their respective branches. A structured, both open and closed ended questionnaire was used to collect data. Descriptive statistics were used to analyze the data and presented quantitatively in a manageable summary form.

\section{RESULTS AND DISCUSSIONS}

The researcher administered 41 questionnaires to branch managers of the specified coffee house branches in Nairobi, Mombasa and Nakuru. The response rate was $90 \%(37 / 41)$ which was statistically representative. The respondents were further requested to state their gender 
where $68 \%$ were men and $32 \%$ were women hence the study would not suffer from gender biasness. Further, the study found that $54 \%$ of the respondents indicated that they were aged (between 41 to 50 years), 32\% of the respondents indicated (30 to 40 years), whereas 14\% of the respondents indicated to be (50 years and above). With the level of education, the study found that $62 \%$ of the respondents indicated that they had attained education up to an undergraduate level, $24 \%$ had reached post-graduate level whereas only $14 \%$ had reached the diploma level. Finally, the study's findings on the time of service established that majority of the respondents had served the coffee house for a duration of more than 10 years (47\%), followed by 6 to 10 years (33\%), 1-5 years (15\%), and 5\% represented those who had worked for less than one year. This is an indication that majority of the respondents had served in the coffee house for a duration of more than five years and so would give credible information with regards to the study.

\section{DESCRIPTIVE STATISTICS}

The respondents were requested to indicate their level of agreement with regards to individual perceptions of total quality management principles. The responses were rated on a Likert scale where: 1 represents strongly disagree, 2, disagree, 3, neutral, 4, agree and 5, strongly agree.

Table 1: Continuous Process Improvement

\begin{tabular}{|c|c|c|c|}
\hline Statement on Continuous Process Improvement & $\mathbf{N}$ & Mean & $\begin{array}{l}\text { Std. } \\
\text { Deviation }\end{array}$ \\
\hline $\begin{array}{l}\text { The branches' operations/processes are constantly assessed } \\
\text { and evaluated }\end{array}$ & 37 & 3.9854 & .34119 \\
\hline $\begin{array}{l}\text { The cost of product/service quality exceeds perceived } \\
\text { product/service benefits }\end{array}$ & 37 & 2.3610 & .64255 \\
\hline $\begin{array}{l}\text { The organization is in tandem with industry standards of } \\
\text { operation }\end{array}$ & 37 & 3.4098 & .95790 \\
\hline $\begin{array}{l}\text { Employees are involved in continuous process } \\
\text { improvement programs in the organization }\end{array}$ & 37 & 3.8585 & .88435 \\
\hline $\begin{array}{l}\text { There is training and development, reward and benefits } \\
\text { schemes for employees achieving set targets }\end{array}$ & 37 & 3.8073 & .90851 \\
\hline
\end{tabular}

From the findings in Table 1 above, $65 \%(n=24 / 37)$, agreed that the branches' operations/processes were constantly assessed and evaluated, 54\% ( $n=20 / 37)$ of the employees involved in continuous process improvement programs in the organization and $48.6 \%(n=18 / 37)$ also agreed there was training and development, reward and benefits schemes for employees achieving set organization targets and 67.6\% ( $n=25 / 37)$ of the respondents did not know whether the organization was in line with industry standards of operation. Further, $72.9 \%(n=27 / 37)$ of the respondents disagreed to the statement that the cost of product/service quality exceeds perceived product/service benefits. This finding was in line with Matsui (2002), who observed that total quality management can be achieved by constantly pursuing continuous improvement through the involvement of people from all organizational levels. This also portrayed continuous improvement as put forward by Oakland, (1999) that it can be a completely new approach to enhancing creativity and achieving competitive excellence in today's market.

\section{Supplier Partnering}

On supplier partnering, the responses were as follows; $75.6 \%(n=28 / 37)$ of the respondents agreed that the supplier delivery/cycle/lead time was optimum for branch operations, $70.2 \%$ $(n=26 / 37)$ agreed that the products supplied were often in good condition $78.3 \%(n=29 / 37)$ said that the suppliers were involved in the organization policy formulation with regards to procurement standard procedures and the cost of switching a particular supplier was minimal. 
However, $56.7 \%(n=21 / 37)$ of the respondents did not know whether there were measures for gauging supplier performance over a period of time like the supplier performance index.

These findings showed that there was effective supplier partnering in the coffee houses and this concurred with Brownell and Reynolds (2002), Trent, and Callahan, (1993) that in today's business, many buying firms pursue aggressive strategies such as supplier partnering and outsourcing in order to increase their future rate of capabilities improvement.

\section{Customer Satisfaction}

With regards to the customer satisfaction, $78.3 \%$ of the respondents strongly agreed that customer feedback was incorporated in the evaluation of customer service to enhance better performance and $83.8 \%$ agreed that customer retention was mostly because of high product and service perceived performance. Also, 72.9\% agreed that customer complaints were dealt with immediately and with urgency, $78.3 \%$ indicated that market research was undertaken to cater for dynamic customer needs and $81.1 \%$ agreed that the number of customer complaints had reduced to zero over the organizations trade period. These findings discovered that the coffee houses were employing the customer satisfaction strategies in their work in order to maintain their customers and attract new ones. The coffeehouses tend to be motivated by several researchers Anderson, Rungtusanthan and Schroeder (1995), Choi and Eboch (1998), who observed that in turn, higher satisfaction and loyalty leads to improved revenue, profitability, and cash flows.

\section{Quality Control}

\begin{tabular}{|c|c|c|c|}
\hline Statement on Quality Control & $\mathbf{N}$ & Mean & Std. Deviation \\
\hline $\begin{array}{l}\text { A checklist is used for quality control standard operating } \\
\text { procedures }\end{array}$ & 37 & 3.8049 & .98784 \\
\hline Quality control checks and balances are all automated & 37 & 4.0732 & .98464 \\
\hline $\begin{array}{l}\text { There's a quality control framework or manual that serves as a } \\
\text { guideline during quality control procedures }\end{array}$ & 37 & 4.3415 & .91131 \\
\hline Quality control inspections are carried out frequently & 37 & 3.8293 & .80213 \\
\hline $\begin{array}{l}\text { Everyone in the organization is involved in quality control } \\
\text { measures }\end{array}$ & 37 & 3.7073 & .66462 \\
\hline
\end{tabular}

From the study findings in table 2 above, $100 \%(n=37 / 37)$ of the respondents agreed to all the statements that there was a quality control framework or manual that served as a guideline during quality control procedures ; 75.6\% $(n=28 / 37)$ agreed that quality control checks and balances were all automated; $92.8 \%(n=34 / 37)$ said quality control inspections were carried out frequently ; 89.1\% ( $n=33 / 37)$ agreed a checklist was used for quality control standard operating procedures and $81.1 \%(n=30 / 37)$ agreed that everyone in the organization was involved in quality control measures. Flyn, Barbara, Roger,Schroeder and Sadao (1995), Forza, Flippini and Walton (1998) empirical findings, found that to enhance quality control many quality control measures were to be put in place for organizations to be successfully efficient and this is in line with the research findings.

\section{Regression Analysis}

\section{INFERENTIAL STATISTICS}

The regression derived from table 3,4 and 5 depicts the results from the analysis of the inferential statistics. 
Table 3: Table of Coefficients Coefficientsa

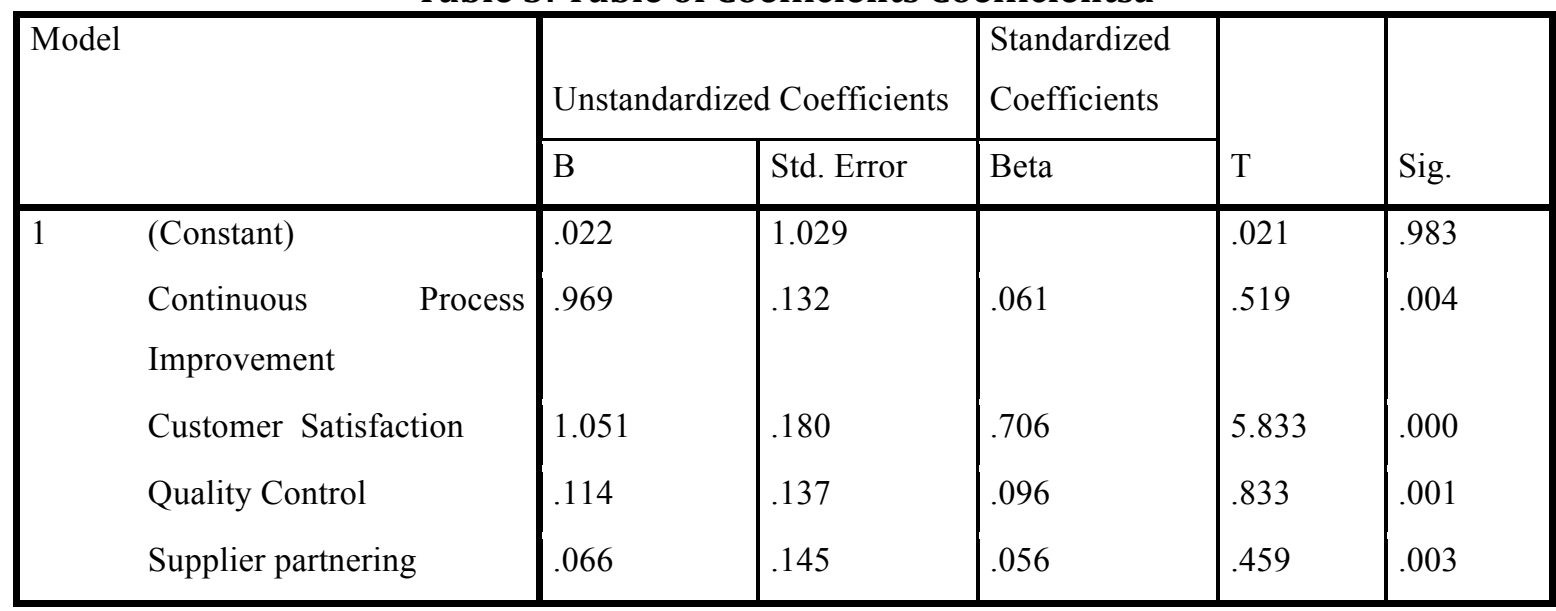

The multiple linear regression equation developed was:

$\mathrm{Y}=0.022+0.969 \mathrm{X} 1+0.066 \mathrm{X} 2+1.051 \mathrm{X} 3+0.114 \mathrm{X} 4+1.029$

Where Y represents Sales Revenue Generation. $\beta 0$ is equal to 0.022. This represents the Constant indicating that if Continuous Process Improvement, Supplier partnering, Customer Focus and Satisfaction and Quality Control are all rated as zero, Sales revenue would be 0.022 units. The coefficient of X1 is 0.969 , which shows that one unit change in Continuous Process Improvement results in 0.969 units increase in Sales revenue. The coefficient of X2 is 0.066, which shows that one unit change in Supplier partnering results in 0.066 units increase in Sales revenue. The coefficient of X3 is 1.051, which shows that one unit change in Customer Satisfaction results in 1.051units increase in Sales revenue. The coefficient of X4 is 0.114 , which shows that one unit change in Quality Control results in 0.114 units increase in Sales

Table 4: Model Summary

\begin{tabular}{|l|l|l|l|l|}
\hline Model & $\mathrm{R}$ & R Square & Adjusted R Square & Std. Error of the Estimate \\
\hline 1 & $.912^{\mathrm{a}}$ & .832 & .816 & .66403 \\
\hline
\end{tabular}

Predictors: (Constant), Supplier partnering, Quality Control, Continuous Process Improvement, Customer Satisfaction

The above table tells us the variation in the dependent variable due to changes in the independent variable. Analysis in the table above shows that the coefficient of determination (the percentage variation in the dependent variable being explained by the changes in the independent variables) R2 equals 0.832 (83.2\%), that is, Continuous Process Improvement, Supplier partnering, Customer Satisfaction, Quality Control leaving only 16.8 $\%$ unexplained. The table below is the analysis of variance (ANOVA) which is intended to investigate whether the variation in the independent variables explains the observed variance in the outcome in this study. The ANOVA results indicate that the independent variables significantly in the $F$-Statistics produced $(F=11.660)$ was significant at the 0 per cent level (Sig. $\mathrm{F}<.005)$ thus confirming the fitness of the model. 
Table 5: Analysis of Variance

\begin{tabular}{|ll|l|l|l|l|l|}
\hline Model & & Sum of Squares & Df & Mean Square & F & Sig. \\
\hline 1 & Regression & 20.565 & 4 & 5.141 & 11.660 & $.000^{\mathrm{a}}$ \\
& Residual & 15.874 & 36 & .441 & & \\
& Total & 36.439 & 40 & & & \\
\hline
\end{tabular}

a. Predictors: (Constant), Supplier partnering, Quality Control, Continuous Process Improvement, Customer

Satisfaction

b. Dependent Variable: Sales revenue

\section{CONCLUSIONS}

This study concludes that Continuous Process Improvement, Supplier Partnering, Customer Satisfaction and Quality Control all impact positively on coffee houses revenue generation. The most important factors to consider in revenue generation is Customer Satisfaction. This is because it had the largest impact on revenue generation in this study than the rest of the variables. One unit change in Customer Satisfaction resulted in 1.051units increase in Sales revenue. Incorporating customer feedback in the evaluation of customer service enhances better performance, dealing with customer complaints with urgency and undertaking market research to cater for the dynamic customer needs were vital in enhancing revenue generation.

\section{Recommendations}

The study recommends the following;

I. Coffee houses should focus more on being in line with industry standards of operation and involve employees more in customer satisfaction programs in the organization.

II. Organizations should have measures for gauging supplier performance over a period of time like the supplier performance index.

III. The role of leadership, employee participation, customer focus, supplier quality management, continual improvement, and organizational culture are apparent for the success of the firm in terms of market share, productivity, profitability and overall revenue generation.

IV. Firms should establish their quality management systems according to the requirement of ISO 9000.

\section{Recommendation for further studies}

The study recommends further research on effects of TQM implementation in service institutions such as the coffeehouses. Further research should also be carried out on the challenges facing the implementation of TQM principles in organizations such as the coffee houses. These findings would supplement the findings in this study and form a reliable literature base.

\section{References}

Anderson, J.C., Rungtusanthan, M., \& Schroeder, R. (1995). A theory of quality Management underlying Deming management method. Academy of Management Review, 19, 472-509.

Anderson.C, \& Sullivan, A. (1993). The Importance of Pay in employee Motivation: Discrepancies between What People say and what they do. Human Resource Management, 43 (4), 381-394.

Belder, D., \& Besterfield, C. (2006). Total Quality Management. Prentice Hall New Jersey, 3rd Edition, 4.

Brownell, S., \& Reynolds, P. (2002). Trying to consume, Journal of Consumer Research, 17 (2), 127-40.

Campanella, J. (2001) .Human Resources Management, 8th Edition Irwin Boston Burn, McGraw-Hill. 
Kirugumi, J. N., Mwenda, L., \& Wachira, A. (2015). Role of total Quality Management in Kenyan Coffee House Revenue Generation. Archives of Business Research, 3(2), 88-96.

Dale, B., \& Schindler, P. (2003). Business Research Methods 8th Edition McGraw-Hill, New York.

Daviron, B., \& Ponte, S. (2005). The coffee paradox: Global markets, commodity trade, and the elusive promise of development. London: Zed Books in association with the CTA.

Forza. M., Flippini, G., \& Walton, M. (1998). Tourism and Leisure Research Methods, Pearson Education.

Flynn.N., Barbara B., Roger G., Schroeder R, \& Sadao, S. (1995). “The Impact of Quality

Management Practices on Performance and Competitive Advantage Decision Science Journal, Vol. 26, No. 5, pp. 659-691.

Howden, D. (2012) .Kenya's coffee wars. The Independent, Retrieved 27 August 2013.

Hoyer, H. (2009). ISO 9000 Quality Systems Handbook. 6th Edition, Burlington MA: Butterworth-Heinemann.

International Coffee Organization (2004). Lessons from the World Coffee Crisis: A serious Problem for Sustainable Development. Submission to UNCTAD XI: Sao Paulo.

Krause, F., Handfield, M. \& Tyler, S. (2006). TQM and the Government. Journal of Quality and Participation, 32, (32), 27-31.

Matsui, J. (2002). The integration of lean management and six sigma. The TQM magazine, 5-18.Management Practices on Performance and Competitive Advantage. Decision Science Journal, 26, 659-691.

Oakland, J. (1999). Total organizational excellence achieving world-class performance. Butterworth Heinemann: Oxford.

Pursglove, H., \& Dale, L. (2005). Are travelers satisfied with Malaysian hotels. International Journal of Contemporary Hospitality Management, 17 (3), 217-27.

Rao, S., Odendaal, A. \& Roodt, G. (1996). Organizational behavior. Cape Town: Prentice-Hall International.

Reeves, J. \& Bednar, G. (1994). Social structural characteristics of psychological empowerment. Academy of Management Journal, 39,483-504.

Sayer, G. (2001). Coffee Futures, Impacts of falling prices on Livelihoods in Uganda. Uganda Coffee Report for Oxfam.

Schiffauerova, J., \& Thomson, A. (2006). Are your satisfied customers loyal, Cornell Hotel and Restaurant Administration Quarterly, 45 (3), 221-34.

Sörqvist, S. \& Vrat, P. (2005). Service quality models: a review, International Journal of Quality \& Reliability Management, 22(9), 913-49.

Trent, V., \& Callahan, A. (1993). Review of Research on Cost of Quality Models and Best Practices. International Journal of Quality \& Reliability Management, 647-669.

Varqa, S. (2008), The Impact of Reform of The Coffee Industry in Kenya on Small and Large Farmers: A research programme carried out in collaboration with the Institute of Development Studies (IDS), of the University of Nairobi, the French Institute for Research in Africa in Nairobi and The Coffee Board of Kenya. September, 2008. The TQM Magazine, 18 (2), 162-173. 